\title{
Stress Indicators and Eating Habits among Working Malaysian Women
}

\author{
Adriana Ortega ${ }^{1}$, Haslinda Abdullah ${ }^{1}$, Nobaya Ahmad $^{2}$ \& Rahimah Ibrahim² \\ ${ }^{1}$ Institute for Social Science Studies, Putra Infoport, Universiti Putra Malaysia, Serdang, Malaysia \\ ${ }^{2}$ Faculty of Human Ecology, Universiti Putra Malaysia, Serdang, Malaysia \\ Correspondence: Adriana Ortega, Institute for Social Science Studies, Health and Social Well-Being of Youth \\ Lab., Putra InfoPort, Universiti Putra Malaysia 43400 UPM Serdang, Selangor Darul Ehsan, Malaysia. Tel: \\ 60-3-8947-1897. E-mail: adryortegaro@gmail.com
}

Received: February 4, 2013 Accepted: March 11, 2013 Online Published: May 2, 2013

doi:10.5539/ass.v9n7p12 URL: http://dx.doi.org/10.5539/ass.v9n7p12

\begin{abstract}
Managing working life and personal life can result in conflicting demands and roles for young professional women in developing countries. This paper focuses on a descriptive analysis of foods related behavior and level of stress indicators of Malaysian urban working women. It also explored the association between foods related behavior indicators and level of stress among these working women in Malaysia. The data was derived from an unpublished report carried based on a study on levels of stress, work environment and food intake patterns among urban working women. Data was collected using a questionnaire consisting of self-reported measures of health, stress symptoms, and food related behavior pattern. The results show that young professional women in Malaysia reported high levels of stress and unhealthy food related behavior patterns; underlining important areas for future research related to working women in Asian communities and workplaces. There is a need to addressed issues related to quality of life and wellbeing of working women in Malaysia by both researchers and by policy makers.
\end{abstract}

Keywords: stress level, foods related behavior, working women

\section{Introduction}

Working women face not only the physical and emotional demands at work, but they are also exposed to other source of stress, for example, household chores, childcare responsibilities, being the caretakers of ill and elderly family members, as well as maintaining the emotional and organizational functioning of their families (Friedman \& Greenhaus, 2000; Williams, 2000; McGoldrick, 1999; Walsh, 1999; Hochschild \& Machung, 1989). Consequently, competing demands (e.g. work vs. family roles) and balancing work and family responsibility have been found to be important sources of stress among working women (e.g. Looker \& Magee, 2002; Perry-Jenkins, Repetti, \& Crouter, 2000). The extent to which a woman subordinates her career aspirations to meet her family needs or vice versa depends on her value systems and priorities, the amount of support she gets from her spouse, the age-based needs of her children, and also depends on the support she gets from the organization she works (e.g. flexibility in working hours, assistance for childcare) (Silver, 1993). A study carried out in Malaysia by Muhammad, Zainab and Jalil (2011) showed that having a supportive supervisor; and accesses to flexi-time at work were associated with reduced work-family conflicts. In their study, Muhammad and colleagues (2011) also observed that family size and husband's income and husbands' attitude towards their wife's job were associated stress among Malaysian working women.

Traditionally, stress has been linked to poor health outcomes such as cardiovascular diseases, musculoskeletal disorders, RSI-repetitive strain injuries, (Hoogendoorn, et al., 2000; Ariëns, et al., 2001). Also, it has been reported that among women and young adults, stress is associated with neck and shoulder pain, decreased fertility health, depression and psychological distress (Siivola, et al., 2004; Sanders \& Bruce, 1997; Negro-Vilar, 1993; Frone, 2000; Umi Adzlin et al., 2011). Moreover, stress has been found to be linked to obesity, bulimia, anorexia, poor food choices and unhealthy food related behavior (Loth et al., 2008; Renie \& Jebb, 2005; Steptoe, et al., 2004; Wadden \& Stunkard, 2002; Liingswiler et al., 1989; O'Connor, 2006; Cederquist, 2005; Canetti et al., 2002). 
Stress has been also found to be an important predictor of binge eating episodes (Pendleton et al., 2001), and associated with a high fat diet and lack of exercise ( $\mathrm{Ng} \&$ Jeffery, 2003). Mental health, anxiety, depression, emotional arousal and moods have been also associated poor eating habits among women (Liu et al., 2007, Match et al., 2003; Wansink, et al., 2002; Canetti et al., 2002; Christensen \& Pettijohn, 2001; Match \& Simons, 2000; Prasad, 1998; Wurtman \& Wurtman, 1989; Greeno \& Wing, 1994; Robbins \& Fray, 1980).

Furthermore, according to the literature, people resort to food and/or engage on impulsive eating when they are feeling stressed, bored, depressed or fatigued (Macht, 1999; Oliver \& Wardle, 1999; Stone \& Brownell, 1994; Willenbring et al., 1986; Lyman, 1982; Mehrabian, 1980). Similarly, the empirical data indicates that people tend to increase their intake of fatty foods and decreased consumption of fruits and vegetables when they are feeling stressed (Habhad et al., 2009: Zellner et al., 2006; Cartwright et al., 2003; Hudd et al., 2000).

Currently Malaysia, a Muslim Nation, is experiencing an increasing number of young educated women actively participating in the workforce, but their quality of working life and their health and wellbeing has not yet been addressed by the conventional management, policy makers or researchers. The available data indicates that in Malaysia the prevalence of psychological distress among working women is 22.8 percent (Umi Adzlin et al., 2011), but there is limited research on work-related stress and its association with mental health and wellbeing among young Malaysian working women. According to Root (2009) there is a lack of occupational risk knowledge among working women in Malaysia; Root argued that this poor awareness of occupational risk could negative impact women's well-being and work performance.

In line with Root's (2009) argument, Abdul Kadir and Bifulco (2010) found in their study that among the Malaysian working women that reported to be suffering with depression, very few had any knowledge about treatments or had sought medical services.

Among the issues related to women's quality of live eating habits and stress induce eating are the most commonly study (e.g. Habhad, Sheldon \& Loeb, 2009; Loth et al., 2008; O'Connor, 2006; Zellner, et al., 2006). However, most of these studies have used lab conditions to recreate stressful situations (Heatherton et al., 1991; Wardle et al., 2000; Haynes et al., 2003); and/or have used student samples (e.g. Sun Y.-H.C. 2008; Match et al., 2005; Loth et al., 2008). The present study, to the authors knowledge, is one of the few descriptive research that surveys the association between foods related behavior pattern and stress within the working women context in Southeast Asia.

\section{Methodology}

This paper was based on secondary data and analysis from a previous unpublished study. The original study examined the associations between levels of stress, work environment and food intake patterns among urban working women in Malaysia. The data was collected using a face to face questionnaire that was administrated by trained enumerators.

\subsection{Participants}

The sample consisted of 541 working women in the Klang Valley region, in Malaysia women; 81.1percentage of them had completed post-secondary education and their age ranged between 17 to 56 years old.

\subsection{Research Instrument}

The questionnaire contained self-reported measures of health, stress symptoms, and food related behavior pattern; as well as objective measures of health behaviors and work context assessment.

Food related behavior patterns were measured with a nine items check list. The items described food related behavior and participants were asked to indicate whether or not they exhibit the food related behavior described by each item (i.e. 'drink coffee every morning'; 'eating makes me feel better when lonely', etc.)

Stress indicators were measure using a 19-items check list; respondent indicated on a 4 point Likert scale how frequent they experience each of the stress related symptoms within the last 6 month. The check list included items such as 'have trouble paying attention', 'experienced periods of confusion', 'sweating excessively', 'heart pounding, etc. This check list was used as proxy to calculate the level of stress by adding the individual items together.

Demographics information was collected from the participants who were asked to indicate their age, race, religion, status, education level, occupational sector in which they worked, monthly income, number of children and number of dependents. Participants were assured of the confidentiality and anonymity of their answers. 


\section{Results}

Descriptive statistics and chi-square test of independence were used to assess the association between food related behavior pattern the level of stress.

The statistical analyses were conducted using IBM $®$ SPSS ${ }^{\circledR}$ Statistics 20 The demographic characteristics are summarized in table 1 . The majority of the women that took part on the study were single (61.4\%) and Muslim (67.8\%). Most of the participants were between the ages 17 and 36 years $(87.2 \%)$, worked in the private sector (91.9), and $68 \%$ of the total sample reported a monthly income of RM600-2100. Interestingly, 68 percent of the sample reported that they had no kids and $74 \%$ had no dependents.

Table 1. Demographic characteristics of the sample

\begin{tabular}{|c|c|c|c|c|c|}
\hline Ethnicity & $\mathbf{N}$ & $(\%)$ & Religion & $\mathbf{N}$ & $(\%)$ \\
\hline Malay & 361 & 66.7 & Muslim & 367 & 67.8 \\
\hline Chinese & 114 & 21.1 & Buddhist & 45 & 8.3 \\
\hline Indian & 63 & 11.6 & Christian & 84 & 15.5 \\
\hline Others & 3 & 0.6 & Hindu & 45 & 8.3 \\
\hline Monthly income & $\mathbf{N}$ & $(\%)$ & Occupational sector & $\mathbf{N}$ & $(\%)$ \\
\hline RM 600-2100 & 353 & 68.0 & Government sector & 20 & 3.7 \\
\hline RM2101-3601 & 128 & 24.7 & Private sector & 497 & 91.9 \\
\hline RM3602-5102 & 31 & 6.0 & Self-employed & 24 & 4.4 \\
\hline RM5103-6603 & 7 & 1.3 & & & \\
\hline Number of children & $\mathbf{N}$ & $(\%)$ & Number of dependents & $\mathbf{N}$ & $(\%)$ \\
\hline $1-2$ children & 101 & 18.6 & 1-2 dependents & 80 & 14.8 \\
\hline 3-4 children & 54 & 9.9 & 3-4 dependents & 40 & 7.4 \\
\hline 5-6 children & 13 & 2.4 & 5-6 dependents & 9 & 1.7 \\
\hline 7-8 children & 0 & 0.0 & $7-8$ dependents & 11 & 2.1 \\
\hline 9-10 children & 5 & 0.9 & None & 401 & 74.1 \\
\hline None & 368 & 68.0 & & & \\
\hline Civil Status & $\mathbf{N}$ & $(\%)$ & Age group & $\mathbf{N}$ & $(\%)$ \\
\hline Single & 332 & 61.4 & $17-36$ years & 472 & 87.2 \\
\hline Married & 201 & 37.2 & $37-46$ years & 45 & 8.3 \\
\hline Divorced & 2 & 0.4 & $47-56$ years & 24 & 4.4 \\
\hline Widow & 6 & 1.1 & & & \\
\hline Education level & $\mathbf{N}$ & $(\%)$ & & & \\
\hline STPM & 38 & 7.1 & & & \\
\hline Certificate & 64 & 11.9 & & & \\
\hline Diploma & 145 & 26.9 & & & \\
\hline Degree & 200 & 37.1 & & & \\
\hline Master & 31 & 5.8 & & & \\
\hline Others & 61 & 11.3 & & & \\
\hline
\end{tabular}

The more commonly reported symptoms were excessive sweating (69.6\%); trembling (64.7\%), chest pain $(60.6 \%)$, neglecting personal appearance $(57.0 \%)$, felling panic $(41.7 \%)$ and performing poorly at work (41.1\%). As stated earlier, the items from the check list were used as proxy to calculate the level of stress. The frequency analysis revealed that 4.8percentage of the sample reported low levels of stress while 42.1 percentage showed moderate levels of stress and 53percentage of the women participating in the study presented high stress levels. 
Table 2 summarizes the frequency in which the stress symptoms were reported by the participant women. The more commonly reported symptoms were excessive sweating $(69.6 \%)$; trembling $(64.7 \%)$, chest pain $(60.6 \%)$, neglecting personal appearance (57.0\%), felling panic (41.7\%) and performing poorly at work (41.1\%). As stated earlier, the items from the check list were used as proxy to calculate the level of stress.

Table 2. Reported frequency of stress symptoms $(\mathrm{N}=541)$

\begin{tabular}{lcccc}
\hline \multicolumn{1}{c}{ Stress symptoms } & \multicolumn{3}{c}{ Frequency (\%) } \\
& Never & Rarely & Sometimes & Often \\
\hline More short-tempered than I used to be & $42(7.8)$ & $155(28.8)$ & $187(34.3)$ & $157(29.1)$ \\
More impatient than I used to be & $40(7.4)$ & $128(23.7)$ & $226(41.9)$ & $145(26.9)$ \\
Don't have enough time to get work done & $44(8.1)$ & $196(36.2)$ & $202(37.3)$ & $99(18.3)$ \\
Unable to meet deadlines & $13(2.4)$ & $89(16.6)$ & $228(42.5)$ & $207(38.5)$ \\
Unable to meet promises to friend & $9(1.7)$ & $99(18.3)$ & $272(50.3)$ & $161(29.8)$ \\
Have been disturbed with continuous phone call & $38(7.1)$ & $147(27.3)$ & $152(28.2)$ & $202(37.5)$ \\
Do not have time to stay in contact with friends and family & $27(5.0)$ & $180(33.3)$ & $183(33.8)$ & $151(27.9)$ \\
Have trouble paying attention & $32(6.0)$ & $160(29.8)$ & $222(41.3)$ & $123(22.9)$ \\
Afraid of losing control & $29(5.4)$ & $114(21.3)$ & $180(33.6)$ & $212(39.6)$ \\
Have avoided people & $32(6.0)$ & $121(22.6)$ & $178(33.3)$ & $204(38.1)$ \\
Experienced periods of confusion & $45(8.4)$ & $119(22.2)$ & $200(37.4)$ & $171(32.0)$ \\
Sweating excessively & $13(2.4)$ & $55(10.3)$ & $94(7.6)$ & $371(69.6)$ \\
Heart pounding & $13(2.4)$ & $85(15.9)$ & $163(30.5)$ & $274(51.2)$ \\
Trembling & $8(1.5)$ & $50(9.3)$ & $131(24.5)$ & $346(64.7)$ \\
Neglected personal appearance & $12(2.2)$ & $97(18.1)$ & $121(22.6)$ & $305(57.0)$ \\
Performed poorly at work & $5(0.9)$ & $106(19.8)$ & $204(38.1)$ & $220(41.1)$ \\
Felt panic & $14(2.6)$ & $90(16.8)$ & $208(38.9)$ & $223(41.7)$ \\
Felt pains in the chest & $22(4.1)$ & $62(11.6)$ & $127(23.7)$ & $324(60.6)$ \\
Felt dizzy spells & $52(9.7)$ & $189(35.3)$ & $188(35.1)$ & $106(19.8)$ \\
\hline
\end{tabular}

Table 3 presents the frequency in which the respondents reported food related behavior indicators. The most commonly food related behavior indicator was 'I eat such a quantity of food, that I end up feeling very stuffed' $(88.17 \%)$, and the least reported was 'Eat something even though not hungry $(49.72 \%)$.

Table 3. Reported frequency of food related behavior $(\mathrm{N}=541)$

\begin{tabular}{lcc}
\hline \multirow{2}{*}{ Food related behavior } & \multicolumn{2}{c}{ Frequency (\%) } \\
& Yes & No \\
\hline Drink coffee every morning & $417(77.18)$ & $124(22.82)$ \\
Eat something even though not hungry & $269(49.72)$ & $272(50.28)$ \\
Feel like eating when bored, but able to "get busy" and get my mind off food & $310(57.30)$ & $231(42.70)$ \\
I eat such a quantity of food, that I end up feeling very stuffed & $477(88.17)$ & $64(11.83)$ \\
Urge to snack when feel pressured & $344(63.69)$ & $197(36.31)$ \\
Eating makes me feel better when lonely & $293(54.26)$ & $248(45.74)$ \\
Eat favorite snack when feel happy & $276(51.02)$ & $265(48.98)$ \\
Food will help me when facing a problem & $347(64.14)$ & $194(35.86)$ \\
\hline
\end{tabular}


The Chi-square $(\chi 2)$ test of independence indicated that level of stress had no significant statistic association with 'drinking coffee every morning', 'eating when bored, but able to "get busy" and get my mind off food', 'eating something even though not hungry' or 'Eating favorite snack when feel happy'.

There were, however, statistical significant associations between level of stress and "I eat such a quantity of food, that I end up feeling very stuffed' $(p<0.01)$; 'Urge to snack when feel pressured' $(p<0.05)$; and agreement with the following statements: 'Eating makes me feel better when lonely' $(\mathrm{p}<0.01)$ and 'Food will help me when facing a problem' $(\mathrm{p}<0.01)$. More specifically, $92.33 \%$ of the respondents that reported high levels of stress, indicated 'I eat such a quantity of food, that I end up feeling very stuffed' while $7.67 \% \operatorname{did} \operatorname{not}\left(\chi^{2}(2)=13.16\right.$, $\mathrm{p}=0.001$ ). Similarly, $67.94 \%$ of those with high levels of stress reported 'Urge to snack when feel pressured', while $32.06 \%$ did not $(\chi 2(2)=7.61, \mathrm{p}=0.02)$.

Among those with high levels stress, $60.62 \%$ agreed with the stamen 'eating makes me feel better when lonely' while $39.38 \%$ did not agreed with such statement $\left(\chi^{2}(2)=16.90 ; \mathrm{p}=0.0001\right)$. Likewise, $71.08 \%$ of those with high levels of stress agree with the stamen 'Food will help me when facing a problem', whilst $28.92 \%$ did not agree $(\chi 2(2)=15.27, \mathrm{p}=0.0001)$.

\section{Discussion}

The present paper examined associations between foods related behavior patterns and stress levels in a sample of Malaysians women using secondary data and analysis from a previous unpublished report. The findings reported in this paper highlight the issue of poor life management of young professional women.

The descriptive analysis showed that $95.2 \%$ of the women that took part of the study had medium to high stress levels. Traditionally, high levels of stress among working women have been explained as a result of competing demands they faced at home and at work. That is, in one hand working women confront the daily occupational hazards and demands at work, and on the other hand they face family \& household related demands at home (Friedman \& Greenhaus, 2000; Williams, 2000; McGoldrick, 1999; Walsh, 1999; Hochschild \& Machung, 1989). Previous research has shown that women report more work stress and more burnout than their male counterparts (Etzion, 1984; Jones \& Fletcher, 1993; Westman \& Etzion, 1995). Earlier studies also have reported that in working couples not only women exhibit higher physiological arousal at weekends than their husbands (Dunne \& Mullins, 1989), but that women's work stress was more likely to spill over to their family members (Grzywacz et al., 2002; Kossek et al., 1999; Jones \& Fletcher, 1993; Haynes et al., 1983). Similarly, recent studies have found that women's work stress negatively impact their family relationships (Harper et al., 2000; Roberts \& Levenson, 2001; Crouter et al., 2001).

Interestingly; however, majority of the women $(61.4 \%)$ that participate in our study reported to be single, while $68 \%$ indicated they did not have children and $74.1 \%$ said they did not have any dependents. Nevertheless, 53 percentages of these women showed high levels of stress. These findings indicate that, in this particular case, work-family balance might not be a source of stress. So, why do these young women showing high levels of stress? According to the demographic data, most of them worked in the private sector $(91.9 \%)$; therefore, is plausible that their psychosocial and physical work environments are the main contributors to their stress levels.

There is unpublished data that suggests that those working in the Malaysian private sector faced double work load and demands in comparison to those working for the public sector. Unfortunately, there is no available data from the public sector against which to compare these results. Nonetheless, our findings do present an alarming snap shot of the level of work-related stress these young women experience in Malaysia

Furthermore, in terms of food related behavior, the frequency analyses showed that those that exhibit high stress levels also indicated that they "(...) eat such a quantity of food, that (...) end up feeling very stuffed"; "Urge to snack when feel pressured' and agreed with the following statements: "Eating makes me feel better when lonely' and 'food will help me when facing a problem". These results are in accordance with previous studies that reported associations between emotional arousal, stress and food relate behavior (e.g. O'Connor, 2006; Cederquist, 2005; Zellner et al., 2006; Weinstein et al., 1997; Stone \& Brownell 1994; Willenbring, et al., 1986; Lyman, 1982; Mehrabian, 1980).

These associations observed in this study between stress \& food related behavior could be their attempt to cope with the demands and emotional discomfort by drawing their attention away from the source of discomfort or threat, that is engaging in avoiding coping strategy to deal with demands and stress at work (Macht et al., 2005, Heartheron \& Baumeister, 1991; Wooley \& Wooley, 1981; Spitzer \& Rodin, 1983). Previous research; however, have showed that avoidance coping strategies do not reduce the impact of stress, but rather become potential source of serious health risks (e.g. Polivy \& Herman, 1999; Wansink et al., 2008; Renie \& Jebb, 2005; Steptoe et 
al., 2004; Wadden \& Stunkard, 2002; Liingswiler et al., 1989; O'Connor, 2006; Cederquist, 2005; Canetti et al., 2002). Unhealthy eating habits, high in fat diets, lack of physical exercise are risk factors for obesity (Ng \& Jeffery, 2003, Mozumdar et al., 2011). In turn, obesity in young people has been found to be associated with type 2 diabetes, hypertension, asthma; increase risk of cancer, coronary heart disease, and arteriosclerosis among young people, as well as to poor body image, self-esteem, depression, anxiety and other psychological disturbance in younger women (Reilly, 2005; Colles et al., 2008; Dixon et al., 2003; Wadden et. al., 2006). Therefore the fact that 87.2 percentage of these women were younger than 37 years old, at the time they completed the survey, and already displaying high levels of stress and unhealthy eating habits is worrisome and a potential public health issue to be tackled.

Thus, the negative effects of stress through food choices and food related behavior in Malaysian young workforce needs to be further investigated. The psychosocial work environments and health risks in Malaysian workplaces warrant further research. Especially because, while research continues focusing on repetitive work and physical work environments, the different sources of stress and health risk that the young workforce and women in Malaysia is currently facing are scarcely known.

The results presented here, although preliminary, underline important areas for future research related to working women in Asian communities and workplaces, these women have to manage their daily life as young professional facing the rapid changes in society and perusing their career development. In line with Root's (2009) argument, poor awareness of occupational risk and lack of information regarding healthy eating habits could negatively impact young working women's well-being, and potentially increased their strain related to their competing roles in society.

Although the sample in this study consisted of single young and independent women, the results indicate that these women have already a compromised health and wellbeing even though they have not yet faced the demands related to women's competing roles (e.g. family-work balance issues). Therefore their poor health and unhealthy habits would have a negative impact in their future as they marry and become care givers of their family, not to mention the consequences for their fertility health and mental wellbeing.

\section{References}

Abdul Kadir, N., \& Bifulco, A. (2010). Malaysian Moslem Mothers' Experience of Depression and Service Use. Culture, Medicine \& Psychiatry, 34(3), 443-467. http://dx.doi.org/10.1007/s11013-010-9183-x

Ahmad, M. S., Fakhr, Z., \& Ahmed, J. (2011). Working women work-life conflict. Business Strategy Series, 12(6), 289-302. http://dx.doi.org/10.1108/17515631111185923

Ariëns, G. A. M., Bongers, P. M., Hoogendoorn, W. E., Houtman, I. L. D., Wal, G., \& Mechelen, W. (2001). High quantitative job demands and low co-worker support are risk factors for neck pain: results of a prospective cohort study. Spine, 26(17), 1896-1903. http://dx.doi.org/10.1097/00007632-200109010-00016

Bernstein, I. L. (1991). Development of taste preferences. In R. C. Bolles (Ed.), The hedonics of taste (pp.143-157). Hillsdale (NJ): Erlbaum.

Bruch, H. (1973). Eating disorders. Obesity, anorexia nervosa, and the person within. New York: Basic Books.

Bruch, H. (1985). Four decades of eating disorders. In D. M. Garner, \& P. E. Garfinkel (Eds.), Handbook of psychotherapy for anorexia nervosa and bulimia (pp. 7-18). New York: Guilford Press.

Canetti, L., Bachar, E., \& Berry, E. M. (2002). Food and emotion. Behavioural Processes, 60(2), 157-164. http://dx.doi.org/10.1016/S0376-6357(02)00082-7

Cartwright, M. Wardle, J., Steggles, N., Simon, A. E., Croker, H., \& Jarvis, M. J. (2003). Stress and dietary practices in adolescents. Health Psychology, 22(4), 362-369. http://dx.doi.org/10.1037/0278-6133.22.4.362

Christensen, L. (1993). Effects of eating behavior on mood: A review of the literature. International Journal of Eating Disorders, 14(2), 171-183. http://dx.doi.org/10.1002/1098-108X(199309)14:2<171::AID-EAT2260140207>3.0.CO;2-U

Christensen, L., \& Pettijohn, L. (2001). Mood and carbohydrate cravings. Appetite, 36, 137-145. http://dx.doi.org/10.1006/appe.2001.0390

Colles, S. L., Dixon, J. B., \& O'Brien, P. E. (2008). Loss of control is central to psychological disturbance associated with binge eating disorder. Obesity, 16(3), 608-614. http://dx.doi.org/10.1038/oby.2007.99 
Crouter, A. C., Bumpus, M. F., Head, M. R., \& McHale, S. M. (2001). Implications of overwork and overload for the quality of men's family relationships. Journal of Marriage and Family, 63, 404-416. http://dx.doi.org/10.1111/j.1741-3737.2001.00404.x

Devlin, M., Jahraus, J., \& Dobrow, I. (2005). Eating disorders. In J. Levenson (Ed.), Textbook of Psychosomatic Medicine (pp. 311-334). Washington, DC: American Psychiatric Association.

Dunne, E. A., \& Mullins, P. M. (1989). Sex differences in physiological and psychophysiological arousal patterns: A study of working couples. Work and Stress, 3, 261-268. http://dx.doi.org/10.1080/02678378908251562

Epel, E., Lapidus, R., McEwen, B., \& Brownell, K. (2001). Stress may add bite to appetite: A laboratory study of stress-induced cortisol and eating behavior in women. Psychoneuroendocrinology, 26, 37-49. http://dx.doi.org/10.1016/S0306-4530(00)00035-4

Etzion, D. (1984). Moderating effect of social support on the stress-burnout relationship. Journal of Applied Psychology, 69(4), 615-622. http://dx.doi.org/10.1037/0021-9010.69.4.615

Fairburn, C. G., \& Harrison, P. J. (2003). Eating Disorders. Lancet, 361, 407-416. http://dx.doi.org/10.1016/S0140-6736(03)12378-1

Folkman, S., \& Lazarus, R. S. (1980). An analysis of coping in a middle-aged community sample. Journal of Health and Social Behavior, 2l, 219-223. http://dx.doi.org/10.2307/2136617

Friedman, S. D., \& Greenhaus, J. H. (2000). Work and family -allies or enemies? What happens when business professionals confront life choices? New York: Oxford University Press. http://dx.doi.org/10.1093/acprof:oso/9780195112757.001.0001

Frone, M. R. (2000). Interpersonal conflict at work and psychological outcomes: Testing a model among young workers. Journal of Occupational Health Psychology, 5(2), 246-255. http://dx.doi.org/10.1037/1076-8998.5.2.246

Gibson, E. L. (2006). Emotional influences on food choice: sensory, physiological and psychological pathways. Physiology \& Behavior, 89(1), 53-61. http://dx.doi.org/10.1016/j.physbeh.2006.01.024

Greeno, C. G., \& Wing, R. R. (1994). Stress-induced eating. Psychology Bulletin, 115(3), 444-464. http://dx.doi.org/10.1037/0033-2909.115.3.444

Grunberg, N. E., \& Straub, R. O. (1992) .The role of gender and taste class in the effects of stress on eating. Health Psychology, 11(2), 97-100. http://dx.doi.org/10.1037/0278-6133.11.2.97

Grzywacz, J. G., Almeida, D. M., \& McDonald, D. A. (2002). Work-family spill over and daily reports of work and family stress in the adult labor force. Family Relations, 51(1), 8-36. http://dx.doi.org/10.1111/j.1741-3729.2002.00028.x

Habhab, S., Sheldon, J. P., \& Loeb, R. C. (2009). The relationship between stress, dietary restraint, and food preferences in women. Appetite, 52(2), 437-444. http://dx.doi.org/10.1016/j.appet.2008.12.006

Harper, J. M., Schaalje, B. G., \& Sandberg, J. G. (2000). Daily hassles, intimacy, and marital quality in later life marriages. The American Journal of Family Therapy, 28, 1-18. http://dx.doi.org/10.1080/019261800261770

Haynes, C., Lee, M. D., \& Yeomans, M. R. (2003). Interactive effects of stress, dietary restraint, and disinhibition on appetite. Eating Behaviour, 4, 369-383. http://dx.doi.org/10.1016/j.eatbeh.2003.07.005

Haynes, S. G., Eaker, E. D., \& Feinleib, M. (1983). Spouse behavior and coronary heart disease in men: Prospective results from the Framingham heart study. I. Concordance of risk factors and the relationship of psychosocial status to coronary incidence. American Journal of Epidemiology, 118, 1-2.

Heatherton, T. F., Herman, C. P., \& Polivy J. (1991). Effects of physical threat and ego threat on eating behavior. Journal of Personality and Social Psychology, 60, 138-143. http://dx.doi.org/10.1037/0022-3514.60.1.138

Herman, C. P., \& Mack, D. (1975). Restrained and unrestrained eating. Journal of Personality, 43, 647-660. http://dx.doi.org/10.1111/j.1467-6494.1975.tb00727.x

Herman, C. P., \& Polivy, J. (1980). Restrained eating. In A. J. Stunkard (Ed.), Obesity Philadelphia: Saunders.

Herman, C. P., Polivy, J. (1984). A boundary model for the regulation of eating. In A. J. Stunkard \& E. Stellar (Eds.), Eating and its disorders (pp.141-156). New York: Raven. 
Hochschild, A. R., \& Machung, A. (1989). The Second Shift: Working Parents and the Revolution at Home. New York: Viking Penguin.

Hoogendoorn, W. E., Poppel, M. N. M., Koes, B. W., \& Bouter, L. M. (2000). Systematic review of psychosocial factors at work and private life as risk factors for back pain. Spine, 25, 2114-2125. http://dx.doi.org/10.1097/00007632-200008150-00017

Hudd et al. (2000). Stress at college: Effects on health habits, health status and self-esteem. College Student Journal, 34(2), 217-227.

Jones, F., \& Fletcher, B. C. (1993). An empirical study of occupational stress transmission in working couples. Human Relations, 40, 881-903. http://dx.doi.org/10.1177/001872679304600705

Kaplan, H. L, \& Kaplan, H. S. (1957). The psychosomatic concept of obesity. Journal of Nervous and Mental Diseases, 125(2), 181-201.

Kossek, E. E., Noe, R. A., \& DeMarr, B. J. (1999). Work-family role synthesis: Individual and organizational determinants. International Journal of Conflict Management, 10, 102-129. http://dx.doi.org/10.1108/eb022820

Lingswiler, V. M., Crowther, J. H., \& Stephens, M. A. P. (1989). Affective and cognitive antecedents to eating episodes in bulimia and binge eating. International Journal of Eating Disorders, 8, 533-539. http://dx.doi.org/10.1002/1098-108X(198909)8:5<533::AID-EAT2260080505>3.0.CO;2-O

Liu et al. (2007). Perceived stress, depression and food consumption frequency in the college students of China seven cities. Physiology \& Behavior, 92, 748-754. http://dx.doi.org/10.1016/j.physbeh.2007.05.068

Looker, D. E., \& Magee, P. A. (2002). Gender and work: The occupational expectations of young women and men in the 1990s. Gender Issues, 18, 74-88. http://dx.doi.org/10.1007/s12147-000-0012-3

Loth, K., Berg, P., Eisenberg, M., \& Neumark-Sztainer, D. (2008). Stressful life events and disordered eating behaviors: Findings from Project EAT. Journal of Adolescent Healt, 43, 514-516. http://dx.doi.org/10.1016/j.jadohealth.2008.03.007

Lyman, B. (1982). The nutritional values and food group characteristics of food preferred during various emotions. Journal of Psychology, 112, 121-127. http://dx.doi.org/10.1080/00223980.1982.9923544

Macht, J. G., \& Ellgring, H. (2003). Emotions in overweight and normal-weight women immediately after eating foods differing in energy. Physiology and Behavior, 80, 367-374. http://dx.doi.org/10.1016/j.physbeh.2003.08.012

Macht, M. (1999). Characteristics of eating in anger, fear, sadness and joy. Appetite, 33, 129-139. http://dx.doi.org/10.1006/appe.1999.0236

Macht, M., Haupt, C., \& Ellgring, H. (2005). The perceived function of eating is changed during examination stress: A field study. Eating Behaviors, 6, 109-112. http://dx.doi.org/10.1016/j.eatbeh.2004.09.001

Match, M., \& Simons, G. (2000). Emotion and eating in everyday life. Appetite, 35, 65-71. http://dx.doi.org/10.1006/appe.2000.0325

McGoldrick, M. (1999). Women and the family life cycle. In B. Carter, \& M. McGoldrickb (Eds.), The expanded family life cycle: Individual, family, and social perspectives. Boston, MA: Allyn \& Bacon.

Mehrabian, A. (1980). Basic dimensions for a general psychological theory: Implications for personality, social, environmental, and developmental studies. Oelgeschlager, Gunn \& Hain, Cambridge, Mass.

Negro-Vilar, A. (1993). Stress and other environmental factors affecting fertility in men and women: overview. Environmental Health Perspectives, 101(2), 59-64. http://dx.doi.org/10.1289/ehp.93101s259

Ng, D. M., \& Jeffery, R. W. (2003). Relationships between perceived stress and health behaviors in a sample of working adults. Health Psychology, 22(6), 638-642. http://dx.doi.org/10.1037/0278-6133.22.6.638

Oliver, G., \& Wardle, J. (1999). Perceived effect of stress on food choice. Physiology and Behavior, 66, 511-515. http://dx.doi.org/10.1016/S0031-9384(98)00322-9

Oliver, G., Wardle, J., \& Gibson, E. L. (2000). Stress and food choice: a laboratory study. Psychosomatic Medicine, 62(6), 853-865.

Pendleton, W., Poston, S., \& Goodrick, R. (1988). Negative stress and the outcome of treatment for binge eating. Eating Disorders, 9(4), 351-360. http://dx.doi.org/10.1080/106402601753454912 
Perry-Jenkins, A., Repetti, R. L., \& Crouter, A. C. (2000). Work and family in the 1990s. Journal of Marriage and the Family, 62, 981-998. http://dx.doi.org/10.1111/j.1741-3737.2000.00981.x

Polivy, J., \& Herman, C. P. (1999). Distress and eating: Why do dieters overeat? International journal of Eating Disorders, 26 , 153-164. http://dx.doi.org/10.1002/(SICI)1098-108X(199909)26:2<153::AID-EAT4>3.0.CO;2-R

Polivy, J., Herman, C. P., \& McFarlane, T. (1994). Effects of Anxiety on eating: does palatability moderate distress-induced overeating? Journal of Abnormal Psychology, 103, 505-510. http://dx.doi.org/10.1037/0021-843X.103.3.505

Prasad, C. (1998). Food, mood and health: a neurobiological outlook. Brazilian Journal of Medical and Biological Research, 31(12), 1517-1527. http://dx.doi.org/10.1590/S0100-879X1998001200002

Rand, C., \& Stunkard, A. J. (1978). Obesity and psychoanalysis. American Journal of Psychiatry, 135, 547-551.

Reilly, J. J. (2005). Descriptive epidemiological and health consequences of childhood obesity. Best Practice \& $\begin{array}{lllll}\text { Research Clinical Endocrinology } \& \text { metabolism, } & \text { 19(3), } & \text { 327-341. }\end{array}$ http://dx.doi.org/10.1016/j.beem.2005.04.002

Rennie, K. L., \& Jebb, S. A. (2005). Prevalence of obesity in Great Britain. Obesity Reviews, 6(1), 11-12. http://dx.doi.org/10.1111/j.1467-789X.2005.00164.x

Robbins, T. W., \& Fray, P. J. (1980). Stress-induced eating: Fact, fiction, or misunderstanding? Appetite, 1, 103-133. http://dx.doi.org/10.1016/S0195-6663(80)80015-8

Roberts, N. A., \& Levenson, R. W. (2001). The remains of the workday: Impact of job stress and exhaustion on marital interaction in police couples. Journal of Marriage and the Family, 63, 1052-1067. http://dx.doi.org/10.1111/j.1741-3737.2001.01052.x

Root, R. (2009). Hazarding Health: Experiences of Body, Work, and Risk among Factory Women in Malaysia. Health Care for Women International, 30(10), 903-918. http://dx.doi.org/10.1080/07399330903042807

Ruderman, A. J. (1986). Dietary restrain: a theoretical and empirical review. Psychological Bulletin, 99, 247-262. http://dx.doi.org/10.1037/0033-2909.99.2.247

Sanders, K. A., \& Bruce, N. W. (1997). A prospective study of psychosocial stress and fertility in women. Human Reproduction, 12(10), 2324-2329. http://dx.doi.org/10.1093/humrep/12.10.2324

Schmid, J., Kirchengast, S., Vytiska-Binstorfer, E., \& Huber, J. (2004). Infertility caused by PCOS-health-related quality of life among Austrian and Moslem immigrant women in Austria. Human Reproduction, 19(10), 2251-2257. http://dx.doi.org/10.1093/humrep/deh432

Schotte, D. E., Cools, J., \& McNally, R. J. (1990). Film-induced negative affect triggers overeating in restrained eaters. Journal of Abnormal Psychology, 99, 317-320. http://dx.doi.org/10.1037/0021-843X.99.3.317

Siivola, S. M., Levoska, S., Latvala, K., Hoskio, E., Vanharanta, H., \& Keinänen-Kiukaanniemi, S. (2004). Predictive Factors for Neck and Shoulder Pain: A Longitudinal Study in Young Adults. Spine, 29(15), 1662-1669. http://dx.doi.org/10.1097/01.BRS.0000133644.29390.43

Spitzer, L., \& Rodin, J. (1983). Arousal-induced eating: conventional wisdom or empirics findings? In J. Capiocco, \& R. Petty (Eds.), Social Psychophysiology. New York: Guilford Press

Steptoe, A., Kunz-Ebrecht, S. R., Brydon, L., \& Wardle, J. (2004). Central adiposity and cortisol responses to waking in middle-aged men and women. International journal of obesity and related metabolic disorders, 28, 1168-1173. http://dx.doi.org/10.1038/sj.ijo.0802715

Steptoe, A., Lipsey, Z., \& Wardle, J. (1998). Stress, hassles and variations in alcohol consumption, food choice and physical exercise. British Journal of Health Psychology, 3, 51-63. http://dx.doi.org/10.1111/j.2044-8287.1998.tb00555.x

Stone, A. A., \& Brownell, K. (1994). The stress eating paradox: Multiple daily measurements in adult males and females. Psychology and Health, 9, 425-436. http://dx.doi.org/10.1080/08870449408407469

Sun, Y. H. C. (2008). Health concern, food choice motives, and attitudes toward healthy eating: The mediating role of food choice motives. Appetite, 51(1), 42-49. http://dx.doi.org/10.1016/j.appet.2007.11.004

Torres, S. J., \& Nowson, C. A. (2007). Relationship between stress, eating behavior, and obesity. Nutrition, 23(11-12), 887-894. http://dx.doi.org/10.1016/j.nut.2007.08.008 
Umi Adzlin, S., Marhani, M, Salina, A. A., Zam, R. Z., Razali, R., Rozhan Sharif, M. R., \& Azrul Rozaiman, A. (2011). Prevalence of Psychological Distress and Depressive Disorders among Married Working Women in Malaysia. Malaysian Journal of Psychiatry, 20(1), 47-58.

Wadden, T. A., Butryn, M. L., Sarwer, D. B., Fabricatore, A. N., Crerand, C. E., Lipschutz, P. E., ... Williams, N. N. (2006). Comparison of psychosocial status in treatment-seeking women with class III vs. class I-II obesity. Surgery for Obesity and Related Diseases, 2(2), 138-145. http://dx.doi.org/10.1016/j.soard.2006.03.016

Walsh, F. (1999). Families in later life: Challenges and opportunity. In B. Carter, \& M. McGoldrick (Eds.), The expanded family life cycle: Individual, family and social perspectives.

Wansink, B., Cheney, M. M., \& Chan, N. (2003). Exploring comfort food preferences across ages and gender. Physiology \& Behavior, 79(4-5), 739-747. http://dx.doi.org/10.1016/S0031-9384(03)00203-8

Wansink, B., Sonka, S. T., \& Cheney, M., M. (2003). A cultural hedonic framework for increasing the consumption of unfamiliar foods: soy acceptance in Russia and Columbia. Review of Agricultural Economics, 24(2), 353-365. http://dx.doi.org/10.1111/1467-9353.00102

Wardle, J, Steptoe, A, Oliver, G., \& Lipsey, Z. (2000). Stress, dietary restraint and food intake. Journal of Psychosomatic Research, 48, 195-202. http://dx.doi.org/10.1016/S0022-3999(00)00076-3

Weinstein, S. E., Shide, D. J., \& Rolls, B. J. (1997). Changes in food intake in response to stress in men and women: Psychosocial factors. Appetite, 28, 7-18. http://dx.doi.org/10.1006/appe.1996.0056

Westman, M., \& Etzion, D. (1995). Crossover of stress, strain and resources from one spouse to another. Journal of Organizational Behavior, 16, 169-181. http://dx.doi.org/10.1002/job.4030160207

Willenbring, M., L., Levine, A., S., \& Morely, J. E. (1986). Stress induced eating and food preference in humans: a pilot study. International Journal of Eating Disorders, 5(5), 855-864. http://dx.doi.org/10.1002/1098-108X(198607)5:5<855::AID-EAT2260050507>3.0.CO;2-O

Williams, J. (2000). Unbending gender: Why work and family conflict and what to do about it. New York: Oxford University Press.

Wingard, D., Berkman, L., \& Brand, R. J. (1982). A Multivariate analysis of health-related practices and nine year mortality follow-up of the Alameda County Study. American Journal of Epidemiology, 116(5), 765-775.

Wooley, S. C., \& Wooley, O. W. (1981). Overeating as substance abuse. Advances in Substance Abuse, 2, 41-68.

Wurtman, R. J., \& Wurtman, J. J. (1989). Carbohydrates and depression. Scientific American, 260(1), 68-75. http://dx.doi.org/10.1038/scientificamerican0189-68

Zellner, D., Loaiza, S., Gonalez, Z., Pita, J., Morales, J., Pecora, D., \& Wolf, A. (2006). Food selection changes under stress. Psychology and Behavior, 87, 798-793.

\section{Copyrights}

Copyright for this article is retained by the author(s), with first publication rights granted to the journal.

This is an open-access article distributed under the terms and conditions of the Creative Commons Attribution license (http://creativecommons.org/licenses/by/3.0/). 